\title{
Professional Securities Analysts Meet Professors Of Financial Analysis: A Pilot Study Of Financial Statement Assessment Differences
}

Robert L. Webster, Ouachita Baptist University, USA Jeanie Curry, Ouachita Baptist University, USA

\begin{abstract}
This multivariate behavioral research investigates whether the financial assessments made by professors of financial analysis differ from those made by private sector financial analysts. Professors of financial analysis and professional private sector securities analysts were put into separate groups for the study. Members of the two groups were asked by way of a mailed survey to analyze multi-year comparative financial statements of a business enterprise using variables related to liquidity, long term debt, cash flow, dividend prospects, profitability, and overall financial condition. The study found a significant statistical difference in assessment results of the analysts and the professors. These results indicate that general purpose financial statements convey different information to the two user groups. The paper describes the data collection process, statistical analysis, and results of the research as well as limitations and a call for additional research.
\end{abstract}

Keywords: Financial analysis, group dynamics, group differences

\section{INTRODUCTION}<smiles>[C]1C=CCCC1</smiles>

tatement of Financial Accounting Concepts No.1 promulgated by the Financial Accounting Standards Board (FASB, 1978) established that the overall purpose of financial reporting is to give outside users information that will enhance their ability to analyze financial information and make business and economic decisions. Accordingly, effective financial reporting should meet the following three broad objectives: (1) information must be useful in making investment and credit decisions, (2) information must be useful in assessing cash flow prospects, and (3) useful information concerning the resources of the enterprise, claims to those resources, and changes in resources must be provided. (FASB, 1978).

The financial reporting objectives are derived from the informational needs of external users. These users lack the authority to prescribe what information they want and what format such desired information must take (SFAC No. 1, 1978); therefore, they must rely on the information communicated by management.

The FASB recognizes that there are many potential groups of financial information users and that financial reporting must attempt to satisfy each group simultaneously. Over the years, a number of studies have questioned whether or not current systems of financial reporting meet the needs of diverse user groups. Abdel-khalik (1971) proposed that the informational needs of users are dynamic and therefore subject to change over time. Hendriksen (1982) pondered how we can be sure that current disclosure rules meet the informational needs of users. Johnson (1992) questioned if informational needs of users might not differ according to user group affiliation.

This research investigates the affects of user group differences when performing financial analysis of a firm using a set of comparative financial statements. The research specifically seeks to determine if a financial statement 
user's professional employment group affiliation affects his or her analysis of the financial condition of a business enterprise.

\section{LITERATURE REVIEW}

In the specific domain of financial analysis, Johnson (1992) postulates that financial informational needs may differ by user class. Elliott and Jacobson (1994) express the belief that financial disclosure will change in the future, most likely with the amount of disclosure increasing to meet differing user group needs. Wallman (1995) expresses concern that current financial reporting is not keeping pace with changes in business and may not meet the objective needs of users in the future. McEwen and Hunton (1999) catalog that differing sets of analysts focus on different aspects of reported financial information. Hendriksen and Van Breda (1992) postulate that various user groups may hold to differing objectives in financial reporting, and by extension, view the same financial information differently. Johnson (1992) goes so far as to question if differing user groups do not in fact have differing financial information needs. Frederickson and Miller (2004) found that pro forma disclosure caused nonprofessional investors to perceive earnings announcements as more favorable than did professional analysts when presented with the same information. Allee et al. (2007) suggest that less-sophisticated investors rely significantly more on data that include a pro forma number than on those that do not, while more-sophisticated investors demonstrate the opposite behavior.

Different users/user groups may arrive at different interpretations from identical financial information. It seems plausible that differences in analysis, if existent, could reasonably be related to one's professional employment position or affiliation. Scott (1997) supports this line of logic in his findings that individual analysts and groups are not unanimous in the reaction to financial accounting information. Makhail, Walther, and Willis (1999) detail that analysts following large, intensely watched firms often arrive at varied analytical conclusions concerning the financial condition of a firm. Webster, Ellis and Bryan (2004) found that male and female analysts differ somewhat in their analysis and in their confidence in their analysis.

This research seeks to add to the body of literature by testing if professional employment affiliation is a significant factor in assessing the financial condition of a firm. The research does not attempt to measure if the analysis performed by a specific professional employment group is superior to another, but concentrates on whether or not differences in outcomes of analysis exist between members of separate professional employment groups.

\section{PROBLEM STATEMENT}

It is not known if the assessment of the financial condition of a firm may be affected by the professional employment of the analyst. The central purpose of this study is to test whether financial analysis differs between two professional groups when assessing a firm's financial condition. In the research, one group of analysts works in the university setting and the other group works in the for profit sector of the economy.

\section{SOURCES OF DATA}

The data collected for this study consisted of responses to a mailed questionnaire applicable to an actual but disguised set of comparative financial statements of a publicly traded utility company. The financial statements contained comparative balance sheets, income statements and cash flow statements. The financial statements were from a regulated utility company that had no nuclear exposure and low exposure to any acid rain legislation. A utility was chosen because accounting practices and methods are more standard in this business sector relative to those in other business sectors. Standardization in financial statement preparation was sought in order to reduce the number of variables the participants would encounter. The response instrument provided for an assessment of the financial condition of the company in six categories (detailed in a subsequent section). The survey packet was mailed to 250 professional users of financial statements. There were 125 members targeted in the survey from two different professional groups. The two groups were professional securities analysts and college professors who taught financial analysis. Survey participants were selected at random from two sources. The professors were selected from Hasselback's Accounting Faculty Directory (2006) and the professional securities analysts were selected from the membership of the New York Society of Security Analysts. Of the 250 survey packets mailed, 71 usable responses were returned, for a response rate of just over 28 
percent. Of the 71 responses, 33 were from securities analysts and 38 were from professors.

After compilation of the returned surveys, potential nonresponse bias was investigated. Larson and Catton (1959) demonstrated a now commonly used proxy to test for nonresponse bias. Using their general methodology, models were constructed to test for differences between early and late respondents in each group. No statistically significant differences were found between the early and late responders. Additionally, Berdie (1989) found that even in the event of nonresponse bias in mail surveys, typically the bias did not alter survey findings.

\section{NULL HYPOTHESIS}

1. $\mathbf{H}_{\mathbf{0}}$ : A statistically significant difference does not exist between professors who teach financial analysis and professional private sector securities analysts in assessing the financial condition of a business firm.

\section{DESIGN OF THE STUDY}

The design for this study was one in which a categorical independent variable was measured in order to evaluate its effect on six metric (scaled) dependent variables. The independent class variable was the professional employment affiliation of the responder (either financial analyst or professor).

The six scaled dependent variables (described in the next section) were measures of the respondents' assessments of the firm's future abilities or future financial conditions. These measurements were obtained from respondent scores in the six areas using a seven point Likert scale for each of the six variables. On the scale, one indicated a very low ability rating of the firm and seven indicated a very high ability rating.

The dependent variables were chosen after a review of the financial analysis literature which indicated that analysis should, at a minimum, incorporate measurements of short-term and long-term liquidity, profitability, and cash flow. (Strong, 2001); (Hirt and Block, 2003); (Besley and Brigham, 2005); (Moyer, McGuigan, and Kretlow, 2006). Additionally, Kolb and DeMong (1988), Mayo (2000), as well as Bodie, Kane, and Marcus (2001), indicate that much of the analysis performed on a firm is done by persons external to the firm, and these analysts must make use of existing financial statements. All authors cited immediately above assert that these parties are most interested in liquidity, profitability, and cash flow. These writers also agree that in addition to assessing individual financial areas, a combined assessment of the entity should be made prior to reaching a conclusion concerning the overall well being of the firm. The dependent variables were therefore chosen to incorporate the consensus of thought concerning important aspects of financial analysis utilizing financial statements.

\section{MANOVA DESCRIPTION AND METHODOLOGY}

The data were analyzed by using Multivariate Analysis of Variance (MANOVA). MANOVA is concerned with differences between groups or experimental treatments. MANOVA is termed a multivariate statistical procedure as it is used to assess group differences across multiple dependent metric variables simultaneously (Hair et al, 1998).

MANOVA is deemed particularly useful when employed in conjunction with an experimental design in which the researcher controls and manipulates one or more independent variables to determine the effect on two or more dependent metric variables (Hair et al, 1998). Additionally, MANOVA does away with the problem of a series of individual F-tests (which may lead to increased type 1 errors) by testing the linear combination of all dependent variables simultaneously.

In the study, the six dependent variables are metric variables based upon a scaled input. The use of scale based metric variables is a common practice and is demonstrated and supported by Hebert and Freeman (1992), Hair, Anderson, Tatham, and Black (1998), and Johnson and Wichern (1998). The six dependent variables are listed below along with the independent class variable. 
$\mathrm{Y}_{1}=$ Assessment of the ability of the firm to meet its short-term obligations as they come due.

$\mathrm{Y}_{2}=$ Assessment of the ability of the firm to meet its long-term obligations as they come due.

$\mathrm{Y}_{3}=$ Assessment of the ability of the firm to continue paying its current cash dividend in the future.

$\mathrm{Y}_{4}=$ Assessment of the ability of the firm to increase its common stock cash dividend in the future.

$\mathrm{Y}_{5}=$ Assessment of the ability of the firm to increase its profitability in the future.

$\mathrm{Y}_{6}=$ Assessment of the over-all future financial condition of the firm.

$\mathrm{X}_{1}=$ User group. (Financial Analyst or Professor)

\section{RESULTS}

Table I displays the mean assessment scores reported by the analysts and professors for each of the six dependent variables. Mean scores are computed from responses based on a one (1) through seven (7) scale. The response form is presented at the end of the paper.

Table I

Response Means By Professional Group To Assessment Variables

33 Analysts, 38 Professors

(7 Point Scale)

\begin{tabular}{|c|c|c|}
\hline Variables & $\begin{array}{c}\text { Analysts } \\
\mathbf{n}=\mathbf{3 3}\end{array}$ & $\begin{array}{c}\text { Professors } \\
\mathbf{n}=\mathbf{3 8}\end{array}$ \\
\hline Ability of the firm to meet its short-term obligations & 4.94 & 5.71 \\
\hline Ability of the firm to meet its long-term obligations & 4.61 & 4.97 \\
\hline Ability of the firm to continue paying current cash dividend & 4.73 & 4.97 \\
\hline Ability of the firm to increase cash dividend in the future & 4.03 & 4.34 \\
\hline Ability of the firm to increase profitability in the future & 3.61 & 4.16 \\
\hline Overall assessment of the future financial condition of the firm & 3.91 & 4.63 \\
\hline
\end{tabular}

Table II shows the results of testing the null hypothesis. The results demonstrate that there is a statistically significant difference between the analysis of the professors and the analysts. The observed power of the F-test was .833.

Table II

Manova Results For Hypothesis Of No Difference In Assessments Between Professional Groups

\begin{tabular}{|c|c|c|}
\hline Wilks Lambda & Exact F Value & Significance of F \\
\hline .799 & 2.691 & 0.022 \\
\hline
\end{tabular}

Table III shows the results of post hoc univariate analysis performed. This analysis was undertaken to determine which if any of the individual dependent variables were significant and to determine if only one or two or the variables were instrumental in affecting the outcome of the MANOVA test. As can be seen from the table, the educators had higher mean scores in each of the six areas of assessment. In three of the six areas, the differences between the mean scores of the two groups were statistically different at the 0.05 level.

Table III

Means And Anova Results For Hypothesis Of No Differences In Financial Assessments Between Professional Groups

(7 Point Scale)

\begin{tabular}{|c|c|c|c|c|}
\hline Variables & $\begin{array}{c}\text { Analysts } \\
\mathbf{n}=\mathbf{3 3}\end{array}$ & $\begin{array}{c}\begin{array}{c}\text { Professors } \\
n=38\end{array} \\
\end{array}$ & F- test & $\begin{array}{c}\text { Significance } \\
\text { of } \mathbf{F}\end{array}$ \\
\hline Ability of the firm to meet its short-term obligations & 4.94 & 5.71 & 7.734 & .007 \\
\hline Ability of the firm to meet its long-term obligations & 4.61 & 4.97 & 1.571 & .214 \\
\hline Ability of the firm to continue paying current cash dividend & 4.73 & 4.97 & 0.729 & .396 \\
\hline Ability of the firm to increase cash dividend in the future & 4.03 & 4.34 & 1.240 & .269 \\
\hline Ability of the firm to increase profitability in the future & 3.61 & 4.16 & 3.993 & .050 \\
\hline Overall assessment of the future financial condition of the firm & 3.91 & 4.63 & 7.102 & .010 \\
\hline
\end{tabular}




\section{SUMMARY OF FINDINGS AND DISCUSSION}

The results of the MANOVA showed that there was a significant statistical difference in assessment results of the analysts and the professors. These results are in consonance with the current literature suggesting that differing user groups may draw different conclusions from identical financial information. The separate post hoc ANOVAs performed on each of the six dependent variables yielded results that indicated three of the six variables were significantly different at the 0.05 level. Additionally, the mean scores reported by the professors were higher than those reported by the analysts in absolute terms for each of the six variables. The research indicates that the general purpose financial statements required by the FASB seem to convey somewhat different information to the two groups. Also, the results indicate that analytical conclusions concerning identical financial data may be influenced by professional group membership (professor or securities analyst).

Objective analysis should be accomplished without bias. But, is this possible? In the current research it would seem that each group of users brings to its analysis its own objectives or perspective. This is not particularly surprising however, as often times in other professions two professionals see the same facts but view them differently. In the court room, for instance, the prosecution and the defense are at opposite ends of the opinion spectrum although they are dealing with the same case and the same facts. Securities analysts often vary in their opinions of the value of a stock although presented with the same information. In the current research it may be useful to conclude that analysis is affected by one's professional position even when other variables such as education and experience are taken into account.

The findings of this study are limited, however, and preclude projection to the general population due to a relatively small sample. Additionally, correlation between the dependent variables, although the employment of such variables is called for by the financial literature, may also limit the findings.

Additional research should be undertaken to determine if other variables such as gender, age, and ethic background affect financial analysis.

\section{AUTHOR INFORMATION}

Robert L. Webster (DBA, Louisiana Tech University), holds the George Young Chair of Business and is Chairperson of the Accounting Department at Ouachita Baptist University. Professor Webster's research and publication interests include behavioral aspects of financial analysis and group dynamics and differences in financial analysis.

Jeanie Curry is an Assistant Professor in the Accounting Department at Ouachita Baptist University and is working to complete her dissertation at The University of Mississippi. Her research and publication interests include issues relating to financial reporting, behavioral aspects of financial analysis, and taxation.

\section{REFERENCES}

1. Abdel-khalik, R. 1971. User preference ordering value: a model. The Accounting Review: 457-471.

2. Allee, K.D., N. Bhattacharya, E.L. Black, and T.E. Christensen. 2007. Pro Forma Disclosure and Investor Sophistication: External validation of Experimental Evidence Using Archival Data. Accounting, Organizations \& Society 32 (3): 201-222.

3. Berdie, D. 1989. Reassessing the value of high response rates to mail surveys. Marketing Research 1: 5264.

4. Besley, S. and E. Brigham. 2005. Essentials of Managerial Finance, $13^{\text {th }}$ ed., ThomsonMcGraw-Hill, New York, NY.

5. Bodie, Z., Kane, A., \& Marcus,A. J. 2001. Essentials of Investments, $4^{\text {th }}$ ed., McGraw-Hill Irwin, New York, NY.

6. Elliot, R., and P. Jacobson. 1994. Commentary: Costs and benefits of business information disclosure. Accounting Horizons 8,4: 80-96. 
7. Financial Accounting Standards Board. 1978. Statement of Financial Accounting Concepts No.1: Objectives of Financial Reporting by Business Enterprises. Stamford, Connecticut.

8. Financial Accounting Standards Board. 1980. Statement of Financial Accounting Concepts No. 2: Qualitative Characteristics of Accounting Information. Stamford, Connecticut.

9. $\quad$ Frederickson, J.R and J.S. Miller. 2004. The Effects of Pro Forma Earnings Disclosures on Analysts' and Nonprofessional Investors' Equity valuation Judgments. The Accounting Review 79 (3): 667-686.

10. Hair, J., R. Anderson, R. Tatham, and W. Black. ed. 1998. Multivariate Data Analysis. UpperSaddle River, NJ., Prentice Hall.

11. Hassleback, J.R. 2006. Accounting faculty directory 2006-2007. Upper Saddle River, NJ, Pearson Education, Inc.

12. Hebert, M, and R. Freeman. 1992. Governmental fund operating statements: should the format be standardized? Accounting Horizons: 17-35.

13. Hendriksen, E. and M. Van Breda. ed. 1992. Accounting Theory Homewood, IL., Irwin Press.

14. Hirt, G., and S. Block. 2003. Fundamentals of Investment Management, $7^{\text {th }}$ ed. McGraw-Hill, New York, NY.

15. Johnson, R. and D. Wichern. ed. 1998. Applied Multivariate Statistical Analysis Upper SaddleRiver, NJ., Prentice Hall.

16. Johnson, T. 1992. Research on disclosure. Accounting Horizons: 101-103.

17. Kolb, B. and R. DeMong ed. 1988. Principles of Financial Management Plano, TX., Business Publications, Inc.

18. Larson, R. and W. Catton, Jr. 1959. Can the mail-back bias contribute to the study's validity? American Sociological Review 24: 243-245.

19. Mayo, H. B. 2000. Investments: An Introduction, $6^{\text {th }}$ ed.., Dryden Press, Harcourt College Publishers, Fort Worth, TX.

20. McEwen, R. and J. Hunton. 1999. Is analyst forecast accuracy associated with accounting information use? Accounting Horizons 13,1: 1-16.

21. Mikhail, M., B. Walther, and R. Willis. 1999. Does forecast accuracy matter to security analysts? The Accounting Review 74: 185-200.

22. Moyer, R., J. McGuigan, and W. Kretlow. 2006. Contemporary Financial Management, $10^{\text {th }}$ ed.,Thomson Southwestern, Mason, $\mathrm{OH}$.

23. Scott, W., ed. 1997. Financial Accounting Theory. Upper Saddle River, N.J., Prentice Hall.

24. Strong, R. A. 2001. Practical Investment Management, $2^{\text {nd }}$ ed., South-Western College Publishing, Cincinnati, $\mathrm{OH}$.

25. Wallman, S. 1995. Commentary: The future of accounting and disclosure in an evolving world: the need for dramatic change. Accounting Horizons 9,3: 81-91.

26. Webster, R., S. Ellis, and B. Bryan. 2004. Similarities and differences between the sexes in financial analysis and self-confidence. Academy of Accounting and Financial Studies Journal Vol. 8, No. 1: 89100. 


\section{FINANCIAL STATEMENT ANALYSIS}

\section{Survey Response Sheet}

For each of the six items below, please record your response by circling one of the numbers for each of the six questions. Indicate your assessment of the company based upon your review of the enclosed Financial Statements.

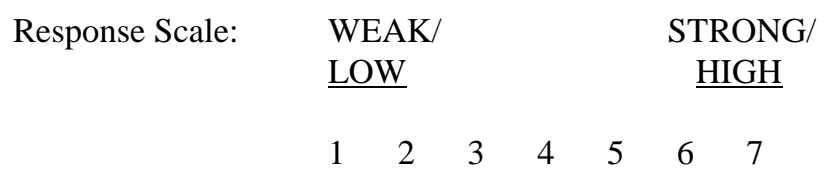

\section{CIRCLE YOUR LEVEL OF ASSESSMENT FOR EACH ITEM}

1. Ability of the firm to meet its short term obligations as they come due.

$$
\begin{array}{lllllll}
1 & 2 & 3 & 4 & 5 & 6 & 7
\end{array}
$$

2. Ability of the firm to meet its long term obligations as they come due.

$$
\begin{array}{lllllll}
1 & 2 & 3 & 4 & 5 & 6 & 7
\end{array}
$$

3. Ability of the firm to maintain its current cash dividend on common stock.

$$
\begin{array}{lllllll}
1 & 2 & 3 & 4 & 5 & 6 & 7
\end{array}
$$

4. Ability of the firm to increase its cash dividend on common stock in the future.

$$
\begin{array}{lllllll}
1 & 2 & 3 & 4 & 5 & 6 & 7
\end{array}
$$

5. Ability of the firm to increase its level of profitability in the future.

$$
\begin{array}{lllllll}
1 & 2 & 3 & 4 & 5 & 6 & 7
\end{array}
$$

6. The overall future financial condition of the firm.

$$
\begin{array}{lllllll}
1 & 2 & 3 & 4 & 5 & 6 & 7
\end{array}
$$

COMMENTS: If you would like to make any additional comments, please do so on the back. 


\section{NOTES}

